\title{
Education To Health Designed For Romany Pupils From a Socially Disadvantaged Environment
}

\author{
Jozef Liba, University of Prešov, Faculty of Education, Ul. 17. Novembra 15, Prešov
}

\begin{abstract}
The paper discusses various adverse parameters of Romany health and lifestyle, and the related socialpathological and health problems found in Romany children (pupils) from a socially disadvantaged environment. The paper presents the latest findings concerning the structure and the content of the lifestyle of Romany pupils from a socially disadvantaged environment; identifies the main problems concerning the education to health in primary school curricula; specifies the position and the potential of school as one of the most important factors in education to health. Furthermore, the paper comments on the results of research implemented by a semi-structured questionnaire, a structured interview (primary school teachers, Romany pedagogical assistants), and an online questionnaire (school managers) by research areas that reflect education to health designed for Romany pupils from a socially disadvantaged environment. The research results enable the author to formulate innovative education strategies and approaches to the implementation of education to health for Romany pupils from a socially disadvantaged environment.
\end{abstract}

\section{Keywords}

Health. Education to health. Romany pupil from a socially disadvantaged environment. Primary school teacher.

\section{Introduction}

Romany lifestyle structure and content can be viewed in both historical and current framework reflected in their usually adverse health stereotypes that are a consequence of the prolonged and stabilized influence of economical, psychosocial, and cultural determinants. They result in a low level of health awareness, insufficient or absent knowledge of health prevention and health attributes, inappropriate dietary habits (irregular, one-sided, and low-quality nutrition), consumption of cheap alcohol and widespread smoking habits in small children, high frequency of socially pathological phenomena (truancy, stealing, fighting, vulgar speech, lack of respect for the neighborhood), insufficient personal and community hygiene, a low housing standard and dirty environment (usually a segregated housing), one-sided motion activities, irresponsible attitude to sexual behavior and reproduction health, underestimation of systematic medical care and a low level of health-care in Romany parents and, consequently, Romany children (without inappropriate over-generalization).

\section{State of the art}

The lifestyle of the Romany population is reflected in the consumption of unhealthy food, e.g., high consumption of fat cheap meat, sausages, sweets, and sweet drinks, low consumption of whole-grain products, fruit, vegetable, milk, and milk products. The dominant part of consumed foods is represented by high-energy but low-nutrition foodstuff. Questionnaire-based research by [19], which covered 102 Romany adults, revealed that only $15.7 \%$ of respondents consumed fresh fruit and 15.8\% ate fresh vegetables at least once a day. At least one portion of milk and milk products (yogurt, cheese, curds) 
a day was consumed by $27.5 \%$ of the respondents; on the other hand, fat products (e.g. sausages) were consumed by $33.3 \%$ of the respondents. Another negative finding concerns the consumption of white flour products a day $-76.5 \%$ of the respondents. Whole-grained products were consumed by only $4 \%$ of the respondents.

These data correspond with [16]'s research found out that $18 \%$ of Romany children do not at all eat fruit or vegetable. Over $50 \%$ of Romany respondents consume fruit and vegetable only twice a week. This is insufficient from the point of view of both fiber, pectin, and vitamin intake. Almost 58\% of Romany children primary school pupils do not consume milk at all or consume it once a week.

Given this situation, it may be concluded that the traditional Romany nutrition prefers fat meals, animal fat, low-quality meat, and meals prepared from flour. The consumption of fruit, vegetable, legumes, and milk is insufficient. All these facts are reflected in frequent obesity: more than a half of the examined Romany population suffers from obesity, in particular, $57 \%$ of men and $58 \%$ of women. All in all, 34.2 \% of the Romany population suffers from obesity [21].

Systematic and regular motion activities in the lifestyle of Romanies are more or less absent. [19] for example, maintain that none of their respondents were involved in daily higher intensity motion activities. $84.3 \%$ of them do not move intensively for the whole week.

Additional significant factors include the prevalence of infectious diseases, injuries, poisoning, and burns as well as a high occurrence of problems with the respiratory system and the musculoskeletal system, sensory disorders, especially eye problems and adnexal abnormalities.

Romany children feature a higher incidence (compared to the majority population) of skin and parasitic diseases, such as salmonellosis, scabies, pediculosis - infestation, pyoderma - purulent skin disease, trachoma - chronic purulent inflammation of the conjunctiva and cornea, mycoses - diseases caused by fungi. [18] maintain that over $80 \%$ of children living in adverse socio-economic conditions suffer from parasitic diseases; polyparasitism and infectious viral hepatitis A have been fairly frequent in all age groups. The same is true of dysentery and salmonellosis in children under one year of age [21]. Romanies are a risk group for tuberculosis and endoparasitosis [20]. A higher incidence of primary congenital glaucoma has also been observed.

The mental disorder (oligophrenia) is fairly common, and phenylketonuria is extremely frequent [1], [3], [4], [5], [6], [12]. An early and tolerated drug addiction is a serious problem in Romanies. Romany children tend to smoke and drink alcoholic beverages, thus imitating the behavioral models of their parents, relatives, and the whole community. Monitoring of Romany primary school pupils [8], [9] revealed occasional smoking and consumption of alcohol as early as the primary school age. Alcohol and tobacco are perceived as a common part of life. [2] draw attention to the relation between the age of developing smoking habits and the intensity of smoking, i.e., the number of smoked tobacco products a day - an early beginning of smoking causes more intensive smoking at a higher age. An analysis of further data, for example, [14] confirms a high prevalence of smoking in Romanies - in all examined age groups and in both genders, it exceeded $50 \%$. [19] found out that only one third (31,4\%) of the examined cohort do not smoke. $66.7 \%$ of the respondents confirmed regular smoking. [16] found out that only 3.3 $\%$ of Romany children reported a lower smoking intensity in their family - the non-smoking borderline for all family members meant less than 5 cigarettes a day.

Almost all communities excessively consume drugs, mainly Ibuprofen, Paracetamol, Diazepam [1]. Many Romanies admit only those diseases that can be directly recognized, such as inflammatory diseases, fevers, injuries, poisoning, burns, influenza, etc. Symptoms of other serious diseases (hereditary, degenerative, autoimmune, tumor, mental diseases) are usually underestimated and neglected and, therefore, they are not cured [14].

The reproductive behavior of Romanies is very different from that of the majority population. The overall fertility in Slovakia is 1.2 child per woman. Sprocha in his 2014 research [21] reports the fertility level of Romany women at 4.3. Importantly, the proportion of Romany mothers under 18 is very high. [16] found out that as many as 52.6\% of Romany families have five and more children.

An important piece of evidence of adverse life conditions that aggravate the health of Romany children is the Romany infant mortality and the mortality of children under five years of age. The infant mortality in the Romany population is 2.5 - 3 times higher than that in the majority population. In the 
case of mortality under five years of age, it is 3.5 times higher. The percentage of babies with low birth weight is almost three times higher than that in the majority population [7].

Another serious problem concerns sexual behavior characterized by frequent sexual partner change and early start of sexual life. This is reflected in the high number of venereal diseases [13]. The fertility of Romany women is higher than that of the majority population in all age categories. The biggest difference concerns the age category of 15-19-year-old women (as much as seven times higher). As to the health awareness and the identification of the Romany population with the specific standards, [15] report that $41.86 \%$ of Romany mothers of the examined sample are smokers compared to $10.15 \%$ of women in the majority population. The term 'smoker' refers to a woman smoking more than one cigarette a day. Tattoos made by laymen is another risk factor.

The Hepa Meta research - information from the Romanies living in East Slovak villages reports that only $47 \%$ of these villages benefit from a sewerage system; $57.5 \%$ have a central drinking water supply; $51 \%$ have a flushing toilet. This situation is projected onto a higher incidence of infectious diseases food gastrointestinal infections and viral hepatitis of type A [11].

The health situation of the Romany community is reflected in the average life expectancy that is shorter by 13 years in Romany men and by 17 years in Romany women compared to the majority population [17].

Some of these data do not necessarily reflect the reality because Romanies like to present halftruths and/or to fable in answering research questions. In addition, one should consider the effect of misunderstanding, distrust, insufficient motivation, reluctance, communication problems, and different value systems. On top of it, relevant statistical data on the health of the Romany population in Slovakia are not available because antidiscrimination measures do not permit to make precise statistics on the health condition of Romanies in Slovakia. Consequently, there is no reliable information on the number and structure of the Romany population, their reproductive characteristics, the development, and the current situation in morbidity, mortality, fertility, and migration. All the data are based on partial regional surveys and estimates.

\section{Method}

Given the outlined background, let us present findings from our research focused on the education to health for Romany children (pupils) from a socially disadvantaged environment implemented within an APVV grant project. The research was implemented at primary schools of the Prešov region in the academic year of 2019/2020. We used a semi-structured interview and a semi-structured questionnaire for primary school managers and teachers who teach Romany pupils from a socially disadvantaged environment, as well as Romany pedagogical assistants. The research sample comprised 83 respondents with at least five-year education experiences with Romany pupils from a socially disadvantaged environment. Owing to the specific conditions and the willingness of respondents to cooperate, the analysis of answers did not distinguish the respondents' gender.

We realize that the obtained information and data are of conditional validity and require a correct and careful interpretation to distinguish between objective findings and potentially subjective standpoints. Nevertheless, our findings reflect the actual situation characterized by an open and rather negative outlook.

\section{Results}

Hygiene of Romany pupils from a socially disadvantaged environment - information, problems:

- Scabies, pediculosis, dirty nails, dirty clothes, often without underwear.

- They do not use physical education attire.

- They do not blow their nose.

- They do not know the sink; they do not know how to use soap.

- The use of toothbrushes and toothpaste is rare.

- They do not know the flush toilet and toilet paper.

- They do not put garbage into baskets; they throw garbage out the window.

- A large family often lives in one room, a minimum of privacy. 
Nutrition of Romany pupils from a socially disadvantaged environment - information, problems:

- Frequently without breakfast.

- Minimum pupils bring brunch to school.

- They almost do not eat fruit and vegetable.

- At school canteens they eat everything (co-financed by the government), primarily meat and sweets.

- They are selective or even reject the food they do not know - problems with boiled vegetable,

vegetable soups and, especially, with fish that is rejected by the majority of Romany children.

- When they receive social benefits, they buy - nutella, croissants, chips, biscuits, salami, white bread, sweetened drinks, and, as a new phenomenon, energetic drinks.

- Absence of eating regularity.

Motion activity of Romany pupils from a socially disadvantaged environment-information, problems:

- Romany pupils from a socially disadvantaged environment-information, problems Romany pupils

from a socially disadvantaged environment are interested in motion activities (mainly boys).

- girls like to shy away from exercises.

- They prefer sport and motion games and all sorts of competition.

- Competitions suffer from their temperament - they can't bear to lose and blame one another for the loss.

- They do not like endurance motion activities, also because most of the older pupils ( $4^{\text {th }}$ year) smoke.

They (especially girls) do not like swimming (most of them are ashamed to change into swimsuits).

Social-pathological phenomena and risk behavior of Romany pupils from a socially disadvantaged environment-information, problems:

- Tolerated smoking of children as a standard part of the family and community life (they smoke as young as primary school age; they collect cigarette butts (almost all 13-14-year-old children smoke).

- The smoking intensity of girls is much lower.

- Sometimes they sniff (toluene), and suck balloons - they smell them.

- Almost all 8-9-year-old pupils have some experiences with alcohol.

- They reject authorities and find it difficult to adapt themselves to a common program.

- Aggressive and explosive behavior - fighting as a game.

- Rude conduct and failure to greet.

- Absenteeism, poor school attendance frequently tolerated by their parents.

- Escaping from school.

- Sometimes vandalism at school premises - when they are not supervised.

- Watching erotic TV channels reflected in the way of talking.

- No supervision after return from school; poor attention paid to them by their parents (adults).

Education and knowledge of health and healthy lifestyle of Romany pupils from a socially disadvantaged environment (family education) - information, problems

- Lack of interest of Romany pupils from a socially disadvantaged environment in education and the tuition process.

- Poor learning results of pupils from a socially disadvantaged environment - poor word-stock; a mixture of Slovak and Romany languages, dirty words, garbled words; many Romanies can only speak Romany language.

- Failure to do homework, to prepare for school, and to bring learning aids to school;

- No daily routine whose part should also be duties.

- Insufficient cooperation between Romany parents and school - parents do not have any stable approach to their duties, to compulsory school attendance of their children, and their manifest little interest in the education results of their children.

- No or poor knowledge of health - "identification" of children with the lifestyle of their parents that insufficiently respects the principles of health, its support and education to health.

- Information of health and healthy lifestyle are acquired almost exclusively at school.

- Insufficient interest of pupils in health issues - even if they know of unhealthy factors.

- They do not take them into consideration (family and community influence).

- They know that if they do not feel well, they should see a doctor.

- Inclusion as an education procedure is questionable in the case of Romany children from a socially 
disadvantaged environment - this situation significantly slows down the process of education.

- Life from day to day without any plan or prognosis.

The current situation and a rather negative outlook are caused by a health-inappropriate and inadequate content of family education. Multiple adverse socio-pathological and health parameters in Romany pupils illustrate a poor and frequently dysfunctional family environment. A Romany family and community mostly represent a negative identification pattern in relation to the child's personality development. This fact hampers an adequate adjustment of Romany children regarding acceptance and interiorization of a pro-health value system.

\section{Discussion}

The outlined situation asks for the responsibility of schools. Many times, primary school necessarily fulfills the task of an exclusive educational institution. Education to health is an important and integral part of the educational objectives, and, therefore, it can direct, adjust, and positively affect the approach of Romany pupils to health and healthy lifestyle.

The extent of education to health (pro-health education) requires a systematic and continuous analysis, evaluation of the actual education situation, and subsequent modification and generation of new, unconventional and innovative education approaches and strategies that reflect the specific nature of the education of Romany pupils from a socially disadvantaged environment and reflect the specific cognitive, communication, psycho-social, and motor capacity of Romany pupils as well as the specific local conditions at schools. Based on the available research findings and many years of experiences of the community of teachers, the following paragraphs present a few education approaches and strategies that positively intervene in the process of Romany pupil education.

All-day education system. An all-day education system provides sufficient space for both preparation and various hobby activities that positively affect the potentially negative influence of the family and community environment. The all-day education system establishes good conditions for improved communication and application of playful and activating methods that can motivate pupils for meaningful activity without violating their emotional link to their parents. In addition to the positive potential projected onto specific results (school results, behavior, attendance, improved communication, free time, socialization, etc.), it can effectively influence health awareness, individual and community hygiene, dietary habits, the daily routine of pupils and, through them, also their parents and relatives.

Interest groups after school, focused on health-supporting topics and activities. Interest groups provide space and establish the necessary conditions for emotionality, playfulness, variety, and specific experiences related to practical life. The objective is to maximize the range of motion activities that reflect the preferences of Romany pupils by stimulating their interest in regular and systematic motion activities.

Information and communication technologies offer an innovative, intriguing, promising and, therefore, effective intervention in education to health. Teachers' experiences indicate the immediate and spontaneous interest of Romany pupils in computers. Digital education provides space for individualization, for one's own pace of work, for the development of strong will and, subsequently, for self-control. Such an educational approach and method establish the necessary preconditions for active learning that saturates not only the cognitive but also the socio-affective areas thus reflecting the educational objectives. This can be projected onto the conative area. From the point of view of Romany pupil motivation, a positive role is played by the content visualization through pictures, diagrams, simple creative tasks, and evaluation of the experiences. Computer education as a modern method which employs multimedia elements increases the dynamics of the education to health, facilitates its systematic implementation within the process of pro-health education of Romany pupils from a socially disadvantaged environment, and establishes space for various inspirational stimuli that promote the education effort.

Pro-health intervention programs (pro-health stimulation programs) - various nation-wide programs, programs of specific ministries, and multiple regional, school, and research programs imply the supportive potential of a systematic education to health. Support programs can contribute to achieving the objectives and tasks of school education by reflecting specific conditions of individual schools, specific local conditions, as well as specific conditions of education of Romany pupils from a socially 
disadvantaged environment. Such programs resulting from the cooperation of all participants offer an innovative potential that exceeds the limits of the established education stereotypes. The range of potential mutual interactions between the teacher and Romany pupils makes it possible to reflect concrete living conditions of Romany pupils from a socially disadvantaged environment and to direct pro-health education towards a pupil-friendly way of presenting individual topics (human body, hygiene, nutrition, drugs, motion activities, first aid). Education objectives and methodological procedures can be related to individualized needs (individual help) and possibilities by reflecting the specific potential of Romany pupils.

Open classes that enable parents to participate in education to health. The above-mentioned forms of education significantly support the process of education to health by generating a positive school and classroom climate as a sociopsychological variable that enters the process of experiencing, evaluating, reflecting the events by its participants. This improves the quality of interpersonal relationships and social processes. No doubt, an improved school and classroom climate is an important determining education process factor because it crucially affects the achievements of pupils, including the results of education to health (pro-health education).

\section{Conclusion and implications}

Given the above-mentioned observations, it may be concluded that the employment of any education strategy and approach heavily depends on the teacher's personality and expertise. The ability of a teacher to work effectively combines with their expertise determine the success of education.

The recommendations presented in this paper are imperative for a primary school teacher professiogram. They pursue the objective of systematic implementation of the health-prevention competence in the undergraduate teacher training (Liba, 2016). A teacher of Romany pupils from a socially disadvantaged environment must educate and, at the same time, prevent his pupils from inappropriate behavior, should be capable of adequate and competent development of cognitive, socioaffective, and psycho-motor aspects of a Romany pupil personality in the process of structuring, stabilizing, and potential interiorizing health standards. A teacher with relevant expertise, including health-prevention expertise, is a necessary condition and guarantee of an effective education to health. A professiogram of a successful teacher in the field of education to health also requires a personality dimension that rests on internal stimuli and belief in effective participation in responding to the problems of Romany pupils from a socially disadvantaged environment. A well-prepared and motivated teacher can generate a system of knowledge, skills, habits, interests, and attitudes in Romany pupils from a socially disadvantaged environment by systematic health-preventive interventions to make the principles of a healthy lifestyle a permanent life value.

Positive shifts, changes, and results in the field of pro-health education of Romany pupils from a socially disadvantaged environment require getting beyond the persistent stereotypes, a change in the unrealistic time-bound plans, and "good intentions" supported by relevant financial stimuli. Successful education is conditioned by a comprehensive knowledge of the existing situation, well-considered and systematic procedures, personal commitment reflecting the requirement of openness and dynamic, intentional, and systematic education. It is a long-term process raising many questions rather than answers.

\section{References}

[1] Bartošovič, I. \& Hegyi, L. (2010). Zdravotné problémy rómskeho etnika. Lekársky obzor, 59(4), pp. 1-11.

[2] Baška, T., Ochaba, R. \& Št́astný, P. (2007). Vybrané aspekty kontroly tabaku. Martin: Národná koalícia pre kontrolu tabaku $v$ SR.

[3] Bernasovský, I. \& Bernasovská, J. (1996). Somatický vývin rómskych detí školského veku. Prešov: Metodické centrum.

[4] Gintner, E. et al. (2001). Health status of Romanies (Gypsies) in the Slovac republic and in the neighbouring countries. Bratislavské lekárske listy. 102 (10), pp. 479-484.

[5] Gintner, E. et al. (2004). Rozdiely zdravotného stavu rôznych regiónov Slovenska. Rómska populácia. Med. Monitor, 2004. [Differences of Health Condition in Various Regions of Slovakia. Romany population]. Monitor Medicíny [Medical Monitor]. 
[6] Horňák, L. (2005). Rómsky žiak v škole. Prešov: PU.

[7] Koval', J. (2012). Úmrtnost' rómskych detí v sociálne znevýhodnenom prostredí. Špeciálny pedagóg. 2(2), pp 31-40.

[8] Liba, J. (2006a). Rómske deti a návykové látky. Zborník príspevkov z medzinárodnej konferencie „Zvyšovanie úrovne socializácie rómskeho etnika prostredníctvom systémov vzdelávania sociálnych a misijných pracovníkov a asistentov učitel'a". Nitra: FSVZ, UKF, pp. 164-170.

[9] Liba, J. (2006b). Skúsenosti a frekvencia kontaktov rómskych žiakov s návykovými látkami. Zborník príspevkov „Zvyšovanie úrovne socializácie rómskej komunity“. Prešov: PF, PU. pp. 129-134.

[10] Liba, J. (2016). Výchova k zdraviu v školskej edukácii. Prešov: PF PU.

[11] Madarasová Gecková A. et al. (2014). Socioeconomic characteristics of the population living in roma settlements and their association with health and health-related behavior. Cent Eur Public health Supplement, 22: pp.57-64.

[12] Matulay, S. (2009). Komunikácia a exklúzia vo vzájomných vztáahoch etnických Slovákov a etnických Rómov na Spiši. Vedecké štúdie Kultúrne kontexty sociálnej interakcie a sociálnej komunikácie v etnicky zmiešaných lokálnych spoločenstuách. Nitra: FSVZ, UKF, pp. 176-205.

[13] Paraličová, Z., Jarčuška, P. \& Hudáčková. D. (2015). Infekčné choroby u marginalizovaných skupín Rómov žijúcich v osadách. SOLEN, Via practica, 12(3), pp. 111-113.

[14] Popper, M., Szeghy, P. \& Šarkozy, Š. (2009). Rómska populácia a zdravie: Analýza situácie na Slovensku. Bratislava: PDCS.

[15] Rimárová, K. \& Dorko. E. (2013). Výsledky štúdií zdravotného stavu minoritnej rómskej populácie v oblasti rastu detí, vplyvu na graviditu a frekvencie infekčných ochorení. Životné podmienky a zdravie Zborník vedeckých prác, ÚVZ, pp. 235-241.

[16] Rimárová, K. (2016). Výsledky prierezovej štúdie o stravovaní rómskej detskej populácie. In: 4. Fórum verejného zdravotníctva, "Výživa a zdravie": recenzovaný zborník abstraktov. Bratislava: SZU, pp. 25-39.

[17] Sepkowitz, K. (2006) Health of the world's Roma population. www thelancet.com 367 (9524): 1707-8.

[18] Solovič, I. et al (2011). Tuberkulóza a parazitózy u marginalizovanej rómskej populácie na Slovensku. (online) Verejné zdravotníctvo. 8(2) http://www.verejnezdravotnictvo.sk

[19] Stávková, J. \& Derflerová Brázdová, Z. (2014). Konzumace ovoce a zelening a jiné stravovací zvyklosti rómske populace. Hygiena. Praha: SZÚ, 59 (4), pp.179-183.

[20] Stupák, M., Stupáková, N. Veselá, J. Guzy, J. \& Mareková, M. (2013) Zdravotný profil marginalizovaných rómskych komunít na Slovensku. In Zborník odborných a vedeckých príspevkov projektov zo ŠF EÚ odborných a vedeckých príspevkov projektov zo ŠF EÚ. from http://www.lf.upjs.sk/ceepm/publikacie/ Stupak.pdf [cit. 16. 8. 2017]

[21] Šupínová, M., Hegyi, L. \& Klement, (2015). Zdravotný stav Rómov na Slovensku. Hygiena, 60 (3), pp. 116-119. 